\title{
Examination of the Savings Practices Drivers Among Zimbabweans
}

\author{
Shepard Makurumidze ${ }^{1^{*}} \quad$ Haabazoka Lubida $^{2} \quad$ Patrick Ngumi $^{3}$ \\ 1.Graduate Business School, Chinhoyi University of Technology, P. Bag 7724, Chinhoyi, Zimbabwe \\ 2.Graduate Business School, University of Zambia, Lusaka, Zambia \\ 3.Institute of Certified Public Accountant of Kenya (ICPAK), Kenya
}

The research was self- funded and is one of the expanded objectives of my $\mathrm{PhD}$ thesis.

\begin{abstract}
Savings are part of the current income for use in the future or the accumulation of financial and non-financial assets and are mobilised by the financial sector which allocates them for productive use in the economy. The study examined the determinants of savings practices among Zimbabweans. A mixed approach was used to establish the drivers of savings among Zimbabweans. Both secondary (Bank deposits and liabilities) and primary data were employed for analysis and testing of hypotheses. A linear regression model was used to explain the savings practice among Zimbabweans and the determinants of savings. 200 depositors randomly selected from the ten provinces as well as 114 key informants were used in the investigation. Although the Zimbabwean majority across gender had a formal bank or mobile account, the predominant are savings for transactional purposes. Savings motivation was related to the selected banker although the provincial residence of accounts was independent to the savings practice. Zimbabwean savings culture has been affected by economic fundamentals, political factors and the credibility of the financial system. There was low financial literacy and depth of the financial system products and services. The savings costs were too high and there was low confidence in the financial system. This called for financial deepening and product development to meet the diverse population needs. This could be supported by broadening the scope of the financial institutions' operating licences. A cost reduction and framework of rewarding savers as well as confidence restoration by providing guarantees against future losses was necessary. Monetary and fiscal policy reforms could also help long term savings.
\end{abstract}

Key terms: financial system, savings practice, bank deposits and liabilities, gross and net savings

DOI: $10.7176 / \mathrm{DCS} / 10-8-04$

Publication date:August $31^{\text {st }} 2020$

\subsection{Background}

Saving is the process of maintaining part of the current income for use in the future or the accumulation of financial and non-financial assets (Najarzadea, Reed and Tasan, 2014). Savings can be described in terms of net savings and gross savings. According to Raj (2004) net savings are generated when disposable personal income is greater than personal expenditure while gross savings include net savings and depreciation allowances for replacement of real assets in the future.

According to Fell (2000) savings are done by three main entities in the economy namely households, business units and government. Raj (2004) noted that households generally save to cover future expenses and for retirement while business units save to finance future investment and government for infrastructural development.

The savings process does not operate in isolation but through the activities of the financial sector. Sometimes the role of the financial sector in the economy is subtle but complex and the sector has a relatively small share of real assets on their balance sheets. The financial sector mobilises savings and allocates credit across space and time (Herring and Santomero, 1996). Apart from providing payment services, the financial sector facilitates business units and households in coping with economic uncertainties by hedging, pooling, sharing and pricing risks. The financial sector transfers funds from surplus units (savers) to deficit units who want to invest in tangible assets (Saunders and Cornett, 2009).

The Zimbabwean government liberalized its financial sector in 1991 and resulted in the establishment of indigenous banks whose number has considerably grown over the years (Brownbridge and Harvey, 1998). However according to the Bankers' Association of Zimbabwe (BAZ) (2013), six commercial banks, two building societies, two merchant banks and one investment bank have closed shop over the years. Arguments for the series of bank collapses have been advanced including economic problems, liquidity crunch and gross mismanagement that involved theft and abuse of depositors' funds. It was the latter argument that has dealt a heavy blow to the financial system as they seemed to have reneged on their fiduciary role of looking after depositors' and investors' funds. Consequently, the investing and saving public has lost confidence in the Zimbabwean financial sector.

The Figure 1.1 (note 1) below summarizes the trends in the Gross Savings (GDS) to Gross Domestic Product (GDP) percentages over time from 1983. Savings rates are a good indicator of a particular country's income and consumption over time. Negative rates imply that household spending is drawing down national wealth. 


\subsection{Statement of the Problem}

According to the RBZ report (2012), the individual deposit rate between the years 2009-2011 averaged 1\% which was far below economic growth rate of 4\%. After 2010 household savings with financial institutions declined sharply by $10 \%$ (ibid) and this has seriously affected the economic performance of the country.

The latest Finscope Survey Zimbabwe (2011) found that 31\% of the adults do not save or put aside some money, a percentage which was far too high compared to fellow SADC countries whose rates were in the range of 20\%. The Standard Zimbabwe (2012) reported that more than half million dollars of cash has been lost while kept at home, a sign that a lot of money was outside the formal banking system. BAZ (2013) noted that such developments have resulted in the financial systems failing to channel financial resources to the productive sectors of the economy resulting in poor economic performance reflected in high unemployment figures around $80 \%$, liquidity crunch, yearly downward revision of GDP targets.

Although savings as a percentage of GDP peaked in $1975(22 \%), 1988(22.1 \%)$ and in $1994(21.8 \%)$, the past decade has witnessed the national savings rates plummeting from the positive $19 \%$ in 1998 to minus savings rates. The paper sought to examine the drivers of the savings culture of Zimbabweans.

\subsection{Research objectives}

The study aimed to:

Establish the drivers of the savings culture among Zimbabweans.

Examine the savings trends among Zimbabweans.

Identify strategies for savings promotion in Zimbabwe.

\subsection{Literature review}

This section reviews the research works by other academics on savings practices and promotion in general and in particular Zimbabwe. It explores the culture of savings among Zimbabweans and the drivers influencing savings culture among Zimbabweans.

Savings are defined as a leakage out of the circular flow of income meaning they are part of income that has been left unconsumed and thus not given back to the circular flow of income but is rather spared for future use (Mankiw, 2007). The forgoing of present consumption for a higher level of future consumption is a better way of defining savings. Savings also are done through the depositing of money in banks or other investment where a future greater return is expected, thus savings should equal investment without this the purpose of savings is distorted. Gardiol (2004) concurred with Mankiw (2007) in defining savings as an act putting aside current income in order to consume or invest later on. The authors went on to allude to the fact that savings can either be kept at home, deposited in a savings account or invested in different types of capital.

Hofstede and Bond (1988) defined culture as the norms and values that shape a person's behaviour as well as one's perception of the world. They argued that culture underlie the prevailing practices and norms in a society. Gray (1988) postulated that culture is an essential element in understanding how social systems change as norms and values exhibit the behaviour of groups of people in their interaction within and across systems. He further confirmed that culture is reserved as a whole for nations even though sub-cultures can subsist within this national culture, which can be used for the level of an organisation, profession or family. There is a pattern of national culture and banking practices across the country. Licht, Goldschmidt and Swartz (2005) noted that values are an essential element of culture taking the form of meanings, symbols and assumptions about what is good or bad, legitimate or illegitimate.

Analysing the nature of the savings in Zimbabwe showed that they are driven by transactional motives. Current research has shown that 31\% of Zimbabwean adults do not save and those who save keep savings at home so that they are able to pay for their living expenses during hard times as well as for school fees and emergences (Finscope, 2011). The survey has also shown that $27 \%$ of the urban adults save at home and $12 \%$ of the adults use savings clubs. Current products and services by financial institutions focus on adults who receive a regular income/salary. Evidence from Finscope (2011) indicated that Zimbabweans save for living expenses, educational expenses and for medical treatment.

According to the Bankers' Association of Zimbabwe (BAZ) (2013) Zimbabwe had around US\$3.8 billion deposits in the banking sector and demand deposits constituted the lion's share of $52 \%$ of total of deposits. Of the total deposits only $17 \%$ were long term deposits placed more than one year, $13 \%$ represent savings accounts and $20 \%$ were short term deposits placed for less than one month. BAZ (2013) attributed the rising household debt as inhibiting meaningful savings in the country. The association concluded that economic productive capacity can only be enhanced if Zimbabwean citizens broaden their savings not only through mechanism like savings accounts with banks but also through mechanisms such as endowments and retirement schemes with insurance companies.

\subsubsection{Drivers influencing savings culture among Zimbabweans}

The determinants of savings in general and their specific effects on government policies are a pivotal force in investment and economic growth. The level of savings at household level is dependent on the marginal propensity 
to save (MPS) of the economic household units. MPS is the proportion of a small change in disposable income that would be saved, instead of being spent on consumption (Carroll, 1996). Generally savings also depend on the willingness and ability of individuals and corporate to save. Grigoli et al (2014) identified income growth and income level, consumer wealth and the rates of return on financial assets as some of the drivers in the economy. Carrol (1996) noted that relative prices of major consumption patterns affect savings because they have a substitution and the income effect. Loayza et al (2000) postulated that high levels of classical and Knightian uncertainty result in higher precautionary savings. Other factors noted by Grigoli et al (2014) as impacting on savings included borrowing constraints, financial depth and financial sector development, demographics, poverty and income distribution, employment level as well fiscal policy.

\subsubsection{Theoretical Framework}

Consist of the permanent income hypothesis (PIH) and the Life Cycle Savings Hypothesis (LCSH). According to Campbell and Mankiw (1989), the permanent income hypothesis implied that people save because they rationally expect their labour income to decline hence they will save for precautionary reasons. Thus savings can be used as a good indicator of declines in labour income. Loayza et al (2000) tested the regression of savings and changes in labour income and the results showed a negative correlation between the variables. Permanent income hypothesis focuses on a representative infinitely lived consumer who equates consumption to permanent of the net of the present value of taxes. The Permanent Income Hypothesis provides an insight as to the reasons households save in view of their envisaged permanent income and permanent consumption. The theory enables us to understand some of the circumstances of saving units that motivate them to save or dissave like wealth, occupation, ability and training received.

The Life Cycle Hypothesis of savings theory was first developed by Modigliani and Brumberg (1954) in response to the contradictory Kuznets' findings on the American savings rates. The theory could not however be published because of the untimely death of Richard Brumberg in August 1954. Using longitudinal data from 1869 to 1938 Kuznets (1946) came to the conclusion that the saving rate in America remained stable even though people's incomes increased significantly during this period. The implication of the conclusion was that the saving rate was constant regardless of economic development over long periods of time. The theory is also referred to as the Modigliani-Brumberg Life Cycle Hypothesis of savings.

Loayza et al (2000) conceded that the key cornerstone of the hypothesis is age related consumer heterogeneity. They also predict that savings follow a lump shaped pattern showing high savings for middle aged consumer units and low savings at young and old ages.

\subsection{Methods}

The research objectives were to establish the drivers of the culture of savings, examine the savings trends among Zimbabweans and identify strategies for savings promotion in Zimbabwe.

The investigation determined the quantitative and the qualitative relationship between the savings culture measured by the total deposits and the savings determinants. In light of the above the data employed in the study was both numerical and non-numerical hence the study adopted a mixed approach.

The investigation adopted exploratory and descriptive research designs. The descriptive approach enabled the study to unpack what is currently going in Zimbabwe in terms of the practice of savings. It invoked the "why" questions requiring the explanatory focus with the view of developing explanations to ascertain trends identified. The study developed a multi-variate regression model of various indicators that explain the savings practice among Zimbabweans. Further the research gathered public opinion regarding the culture of savings among Zimbabweans. Secondary data analysis was employed to re-analyse existing data to test the hypotheses. The research tools used for data collection were tools the questionnaire, interview guide and document analysis guide.

Linear regressions were used as econometric tools for explaining the relationship between savings culture and various factors. Standardised regression coefficients were used to indicate the relative importance of the associated factor to the savings culture among Zimbabweans. The statistical software (SPSS version 20) computed the model and the standardised regression coefficients. A stepwise selection was used where the independent variables that contributed the most in explaining the savings culture were first added. Subsequent factors were included based on their incremental contributions.

\subsection{Results}

A simple random sample of 200 depositors from the ten provincial capitals of the country's was used. The depositors were chosen as they did their banking services at the end of the month. Month end is a very busy period for depositors in Zimbabwe as the majority frequented their banks. The response rate results from the study indicated that the majority of the questionnaires (85\%) were returned compared to $15 \%$ that were not returned as illustrated by Table 1.7.1 (note 2). The high response rate of $85 \%$ was an indication of interest by the respondents on the problem being investigated.

There was $81 \%$ responses rate from Bankers, $82 \%$ response rate from Micro financiers and $100 \%$ response 
rate from RBZ, Ministry of Finance as well as the Deposit Protection Board (note 3). The response rates from the stakeholders' face to face interviews were considered credible for further analysis. According to Punch (2003), response rate from face to face interviews of between $80-85 \%$ is considered good.

\section{Reliability analysis}

According to Brumberg et al (2011) reliability is a measure of assessing the quality of the measurement procedure used to collect data. The Cronbach coefficient alpha automatically generated by SPSS application software showed that the saving culture variables had 0.83 and savings drivers were 0.72 .

Generally the majority of the respondents that participated in the survey had active bank accounts as $97.6 \%$ confirmed as having the active accounts compared to $2.4 \%$ who did not have active accounts from Table 1.7 .3 (note 4)

The majority of respondents (97.6\%) had active bank accounts as indicated by Table 1.7.3 above. Table 1.7.4 (note 5) has a probability value less than 0.05 resulting in the rejection of the null hypothesis of independence between account activity and savings potential. The table shows that there was a relationship between account activity and the practice of savings measured by the Cramer V coefficient of 0.299 .

Savings potential compared with age of respondents.

Tables 1.7.5 (note 6) and 1.7.6 (note 7) show the relationship between the age of respondents and the savings practice measured by the ratio between deposits and liabilities. The correlation coefficient of the two variables measured by the Pearson correlation was -0.104 . This implied that the association is not very strong and is negative. The potential of savings was negatively related to the ages of the respondents. This somehow refuted the Life Cycle hypothesis which relates the savings practice to the ages of the population.

Table 1.7.5 (note 6) further shows that there was a negative relationship or inverse relationship between the savings potential and the age measured by -0.104 . This implied that $10.4 \%$ of the decrease in savings was explained by the demographic makeup of the population. However the probability value (p-value) of 0.177 shown on Table 1.7.6 (note 7) below led to the non-rejection of the null hypothesis that savings potential and age are independent of each other.

The major reason why Zimbabweans saved from Table 1.7.7 and Figure 1.7.1 (note 8), was for property acquisition which had the highest percentage of $26.5 \%$ followed by preparing a better life after retirement $(24.1 \%)$ and the provision of funding for the children's education which had $22.9 \%$. Cumulatively $(73.5 \%)$ the three constituted the main reasons for savings in banks by Zimbabweans. A small percentage of respondents (5.3\%) saved for Travel and Leisure.

\section{Banker and reason for selecting the banker}

Table 1.7.8 below sought to find out if there was any relationship between the reason for saving and the banker selected by the respondent. The probability - value of 0.000 results in the rejection of the null hypothesis of independence between the reason for saving and the banker selected. The two variables were related although the strength of association between the variables measured by the Cramer V in Table 1.7.8 (note 9) was not very strong (0.422).

Table 1.7.9 (note 10) shows a cross tabulation between gender and the type of account held. $84.6 \%$ of the female respondents had savings accounts and $76.9 \%$ of the male respondents had savings accounts. Overally $80.6 \%$ of all the respondents had savings accounts and this confirmed the fact that most Zimbabweans were maintaining accounts for transactional purposes as only $3 \%$ of the female respondents had call accounts and time deposits respectively. Among the male respondents only $1.0 \%$ and $0.0 \%$ of the respondents had time and call accounts respectively. Of the total respondents only $1.8 \%$ and $1.2 \%$ had time and call accounts only. Most Zimbabweans were holding short savings and not long term savings that could be used for investment according to the Keynesian Theory.

According to the statistics from Table 1.7 .10 (note 11), the p- value of 0.040 and the Pearson Chi-square of 10.049 resulted in the rejection of the null hypothesis of independence between gender and the type of account held, rather the two variables were related. The results exhibited the characteristics within the Zimbabwean banking population that the majority were holding savings accounts and females constituted the highest of the account holders.

Table 1.7.11 (note 12) shows the degree of association between gender and the type of account held measured by the Cramer V (0.243). The two random variables were positively related although the association was not very strong.

Table 1.7.12 and Figure 1.7.2 (note 13) show the demography of the accounts held by the respondents according the ten provinces in Zimbabwe. The demography showed that $50 \%$ of the respondents had their accounts held in Harare which is the capital city and has the highest population compared to all the other provinces and is also the industrial hub of the country. Only $0.6 \%$ of the respondents had their accounts held in Masvingo and Matebeleland South provinces respectively.

Table 1.7.13 (note 14) has a p- value of 0.282 which is greater than 0.05 and resulted in the acceptance of the null hypothesis of independence of the savings potential and the province the account was held. Table 1.7.14 (note 
15) shows that the association between the savings potential and the province account is held is not significant ( $R$ $=0.083$ ).

Table 1.7.15 and Figure 1.7.3 (note 16 ) show that $50.6 \%$ of the respondents visited their banks once a month and only $1.8 \%$ of the respondents never visited their banks.

Table 1.7.16 and Figure 1.7.4 (note 17 ) show that the majority of Zimbabweans (85\%) had property as the form of wealth held. Livestock was the least form of wealth held at 24\%, even though the country is an agro-based economy. Most respondents interviewed were formally employed and resided in urban areas hence the reason for holding their wealth in the form of property.

Table 1.7.17 (note 18) shows that $78.8 \%$ of the respondents had the opinion that economic factors affected the restoration of the culture of saving in banks s among Zimbabweans. The factors included the performance of the economy, economy growth, employment among other variables.

From Table 1.7.18 (note 19), credibility of the financial institutions was considered a fertile factor in promoting savings among Zimbabweans. The view was coming from the 2003 and 2004 as well as the 2008 experience where a lot of Zimbabweans lost their savings resulting from the structural changes that took place in the financial sector in those years.

Table 1.7.19 (note 20) shows the respondents' view of the effect of the political factors in the savings practices of Zimbabweans. $65.8 \%$ of the respondents strongly agreed that political factors affected the saving potential of the Zimbabweans. $1.2 \%$ and $1.8 \%$ of the respondents disagreed and strongly disagreed respectively with the view that political factors affected the savings practices among Zimbabweans.

\subsection{Conclusions}

The majority of the respondents interviewed had a formal bank account or mobile account as confirmed by $97.6 \%$ of the respondents. The predominant account held across gender was the savings account. $76.9 \%$ of the male respondents had the account and $80.6 \%$ of the female respondents. Respondents across gender however did not have long term savings.

There was a negative correlation of -0.104 between the savings potential of Zimbabweans and the ages of the respondents. The null hypothesis of independence between age and savings practice was not rejected reinforcing the independence between the two random variables, age and savings potential of the population.

Zimbabweans saved because they wanted to acquire property, prepare retirement or wanted to provide funding for their children's fees. Cumulatively $73.5 \%$ of the respondents highlighted the reasons. The reason for saving was related to the choice of banker as reflected by the rejection of the null hypothesis of independence between the two variables.

The choice of banker was related to the motive of savings by the saver given the correlation coefficient of association. The probability value also resulted in the rejection of the null hypothesis of independence of the two variables.

Generally Zimbabweans had some accounts over the period under review (around 80\%). Savers across the gender divide held these accounts for transactional purposes and not for long term savings. The Chi-square tests (0.040) showed a relation between the type of account held and the gender though the extent of association was not that strong (0.243) among Zimbabwean savers.

The majority of the savers had accounts in the capital city, Harare. The relationship between savings potential and the province account held was not significant (0.083) and the test (probability value of 0.282 ) resulted in the acceptance of the null hypothesis of independence between the two variables.

The majority ( $85 \%$ ) of Zimbabwean savers visited the banks once in a month. Property constituted the major form of wealth held by most savers and a small number of savers had financial assets (17.6\%).

Economic fundamentals seemed to have significantly affected Zimbabweans' savings patterns over the period under review as $78.8 \%$ of the respondents strongly agreed to the notion. Political factors followed next $(65.9 \%)$ followed by the credibility of the financial systems $(46.5 \%)$.

\subsection{Discussions on the saving practices among Zimbabweans}

Savings potentials in Zimbabwe were independent of the age of the savers and the province the account is held, but however dependent upon gender and the choice of banker. The study was inconsistent with the life cycle hypothesis on the age factor. According to Loayza et al (2000) savings are high at the middle age and low at young and old ages. Howcroft et al (2002) in their United Kingdom study found that younger customers valued convenience or time saving potential for an innovation compared to older customers. Further, younger customers considered face to face contact as less important than older customers. However research showed independence between savings patterns and the province account was held. The key factors behind savings practice in Zimbabwe were the economic fundamentals, followed by political factors and the credibility of the financial systems.

According to Anderson et al (1976) and Ross (1989) as cited in Metawa and Almossani (1998), criteria selection of banks has been heavily investigated over the past two decades. Metawa and Almossani (1998) found 
the following attributes as selection criteria for banks; availability of credit, relative's advice and recommendation, friend's advice and recommendation, convenient location, variety of bank services, the quality of services, availability of Automated Machines (ATMs), adequate banking hours, return on investment, friendliness of personnel, understanding of financial needs, special services for women and bank name. The relative importance of the attributes is entirely dependent upon the customers' level of education, age, income and occupation (Metawa and Almossani, 1998).

Every adult across the ten provinces in Zimbabwe had a bank account across gender. However the majority of the respondents did not have long term savings. From the Finscope Consumer Survey (2014), 69\% of the adult Zimbabweans were formally served by formal bank products and services and only $23 \%$ of the adults are financially excluded. The use of the other formal non-banking products was mainly driven by the remittances and insurance.

According to the survey, banking in Zimbabwe had been driven by transactional products and services. The results confirmed the Finscope report findings of 2014, that most Zimbabweans were holding accounts for transaction purposes. This confirmed the fact that most Zimbabweans were of the subsistence type. The Finscope report (2014) found that Zimbabweans saved to enable themselves to pay for living expenses during hard times as well as for education, school fees and other emergencies. According to the Finscope report (2011) the major driver of banking in Zimbabwe is the transactional motive which explains the reason why a great proportion of respondents had accounts with various banking institutions. Most Zimbabweans used their accounts for the purpose of their daily transactions and facilitating payments and receipts through the banking system.

Zimbabweans opened bank accounts for safety reasons, to receive salary or deposit money from the employer and to access loans. The growth in banking by 2014 had been attributed to the use of ATMs and cash point card services.

\subsection{Savings practice implications in Zimbabwe Savings costs and returns}

The cost of saving was very high in Zimbabwe and the returns were very insignificant. Net returns from deposits were being wiped out by the high service charges by the financial institutions. Both depositors and regulators shared the same view.

Banking institutions need to reduce the cost of maintaining a savings account and at the same time increasing returns on savings. The regulatory authorities need to come up with the framework of rewarding savers.

\section{Transactional savings}

The majority of Zimbabweans were holding savings accounts in one form or another for transactional purposes and not for long term savings. The country was currently dissaving as it remained a consumptive economy, a tendency that had turned most economic units into serial borrowers.

Depositors' confidence need to be restored by giving guarantee to depositors and investors that their money will be protected against future losses. Policies should address the liquidity and currency problems in the market both fiscal and monetary as confidence restoration measures.

\section{Low depositors confidence}

There was a low depositors' confidence in the financial services sector owing the financial crises that had rocked the sector over the years. Financial institutions were no longer credible from the perspective of depositors.

The promotion of deposits should be a national strategy like setting aside a month for the promotion of deposits. Other countries in the region have done it for instance South Africa has every July as a National Savings month, although the savings were being hampered by financial literacy, consumerism and unemployment. The month is spearheaded by a non-profit making organisation, South African Savings Institute (SASI). The institute's efforts have seen an increase in savings over time especially from the informal sector.

Long term savings need to be promoted as opposed to transactional savings. The new-normal circumstances that the country finds itself in, where foreign capital and FDI have become unreliable it is prudent to come up with measures that will built a long term savings base.

\section{Financial literacy strategy}

Responsible authorities and the financial institutions in Zimbabwe should have financial literacy programmes that will enable consumers of financial products and services to acquire requisite skills, attitude and behaviour that will make them aware of financial opportunities at their disposal and thus make informed decisions given their financial circumstances.

\section{Financial deepening and product development}

There was need for financial deepening that should include broadening the scope of the operating licences issued by the Central bank. There was also need for the policy instruments to delineate the scope of the financial institutions to minimise services overlap.

Financial institutions needed to develop financial products and services that should target the previously unbanked groups of the society that included MSMEs, women, youth, rural population and the small agricultural 
sector. Thus there was need to judiciously operationalise the Zimbabwe National Inclusion Strategy (2016-2020) promulgated by the Apex Bank towards the end of 2016. This can harness the needed savings for the much starved investment. Gender experts and related organisations should be involved in designing financial regulations to ensure that regulations do not exclude other groups from the mainstream economy.

\section{References}

Ando, A and Modigliani, F. (1963). ' The "Life Cycle” Hypothesis of Savings: Aggregate Implications and tests.' American Economic Association. Volume 53.No. 1, Part 1. Pp 55-84.

Ayadi, R., Schmidt, R. H. and Valverde, S. C. (2009). Investing Diversity in the Banking Sector in Europe: The Performance and Role of Savings Banks. Centre for European Policy Studies. Brussels.

Bhalla, V. K. (2008). Management of Financial Services. $4^{\text {th }}$ Edition. Anmol Publication (Pvt) Ltd. New Delhi. India.

Blumberg, B. Cooper, D. R. and Schindler, P. S. (2011). Business Research Methods. $3^{\text {rd }}$ Edition. McGraw-Hill Higher Education. London.

Bond, P. (1998). Uneven Zimbabwe: A study of finance, development and underdevelopment. African World Press. Asmara, Eritrea.

Brownbridge, M. and Harvey, C. (1998). Banking in Africa. The Impact of Financial Sector Reform Since Independence. Foundation Publishers. Kampala.

Campbell, J. Y., and. Mankiw, N. G. (1989). Consumption, Income, and Interest Rates: Reinterpreting the TimeSeries Evidence. NBER Working Paper 2924. National Bureau of Economic Research, Cambridge, Mass. Processed.

Carroll, C. D. (1996). National Bureau of economic research. Cambridge.

CGAP Annual report (2004). Building Financial Systems for the poor. Washington, D C.

Cooper, H., Donald, R., Schindler, and Pamela, S. (2003). Business Research Methods. $8^{\text {th }}$ Edition. McGraw Hill. Toronto.

Berg, D. W. (2012). Savings and Investments. $1^{\text {st }}$ Edition. Rosen Publishing Group. New York.

Fabozzi, F.J, Modigliani, F, Jones, F.J, and Ferri, M.G. (2011). Foundations of Financial Markets and Institutions. $3^{\text {rd }}$ Edition. Pearson Education. Noida. India.

Fell, L. (2000). An Introduction to Financial Products and Markets. $1^{\text {st }}$ Edition. Continuum. London and New York.

Finscope Consumer Survey Zimbabwe (2014).

Finscope Consumer Survey Zimbabwe (2011)

Friedman, M. (1957). The Permanent Income Hypothesis. Princeton University.

Fry, M. J. (1998). 'Money and Capital or Financial Deepening in Economic Development.' Journal of Money, Credit and Banking. Volume 10, Page 1020-1037.

Gardiol, L. D. (2004). Mobilising Savings: Keys Issues and Good Practices in Savings Promotion. Swiss Agency for Development and Cooperation. Bern.

Herring, R., J. and Santomero, A., M. (1996). The Role of the Financial Sector in Economic Performance. Wharton School. Pennsylvania.

Hofstede, G. and Bond, M. H. (1988). 'The Confucius Connection: From Cultural Roots to Economic Growth.' Organisational Dynamics. Volume 16, Number 4, Page 4-21.

Howcroft, B., Hamilton, R. and Hewer P. (2002). 'Customer attitude and the usage and adoption of home based banking in the United Kingdom.' Emerald Insight International Journal of Bank Marketing. Volume 20. Iss 2, pp. 111-121.

IMF (10/05/17) Financial Soundness, org/external/pubs/ft/fsi/guide/2006/pdf/chp2.pdf.

Keynes, J. M. (1936). The General Theory of Employment, Interest and Money, Macmillan. London.

Kuznet, S. S. (1946). National Income: Summary: Summary of Findings. Arno Press. New York.

Loayza, N., Schmidt-Hebbel, K. and Serven, L. (2000). 'Savings in Developing Countries: An Overview.' The World Bank Economic Review. Volume 14, No. 3. Page 393-414.

Mankiw, N. G. (2007). Principles of Economics. $7^{\text {th }}$ Edition. Harcourt College Publishers. Florida.

Mankiw, N. G. and Laurence, B. N. G. (2010). Macroeconomics and the Financial System. Worth Publishers. New York.

Modigliani, F. (1966). 'The Life Cycle Hypothesis of Saving, the Demand for Wealth and the Supply of Capital.' Social Research. Volume 33, Page 160-217.

Modigliani, F. and Brumberg, R. (1954). 'Utility Analysis and the Consumption Function: An Interpretation of Cross Section Data.' Post Keynesian Economics. Page 388-436.

Mugenda, M. O. and Mugenda, A. G. (2003). Research Methods: Qualitative and Quantitative Approaches. African Centre of Technology Studies. Nairobi, Kenya.

Najarzaden, R., Reed, M. and Tasan, M. (2014). 'Relationship between savings and Economic growth: The case 
of Iran.' Journal for International Business and Economics. Volume 2. Number 4, Pp 107-124.

Phelps, B. (1988). Egalitarianism and the Generation of Inequality, Clarendon Press. Oxford.

Phelps, E. S. and Pollak, R. A. (1968). 'On Second-Best National Savings and Game-Equilibrium Growth.' Review of Economic Studies. Volume 35. Page 185-199.

Punch, K. (2003). Survey Research: The Basics. Sage Publications. London.

Quarterly Banking report, 31 March 2016.Reserve Bank of Zimbabwe.

Raj, D. (2004). Monetary Economics: Theory and Practice. Rajat Publication. New Delhi.

Reserve Bank of Zimbabwe Act. Acts 5/1999 and 22/2001. S.I. 14/2004

Reserve Bank of Zimbabwe. (2012a). Monetary Policy Statement: January 2012. Harare.

Reserve Bank of Zimbabwe. (2012b). Monetary Policy Statement: July 2012. Harare.

Reserve Bank of Zimbabwe. (2013a). Monetary Policy Statement: January 2013. Harare.

Reserve Bank of Zimbabwe. (2014). Monetary Policy Statement: July 2014, Harare.

Reserve Bank of Zimbabwe. (2015). Monetary Policy Statement: July 2015, Harare.

Rose P. S. and Hudgins, S. C. (2008). Bank Management and Financial Services. $7^{\text {th }}$ Edition. McGraw-Hill International Edition. Boston.

Saunders, A and Cornett, M. M. (2009). Financial Markets and Institutions. A Modern Perspective. $2^{\text {nd }}$ Edition. Tata McGraw-Hill Publishing Company Limited. New Delhi.

Saunders, A and Cornett, M. M. (2006). Financial Markets and Institutions. A Risk Management Approach. $5^{\text {nd }}$ Edition. McGraw-Hill. Boston.

Saunders, M., Lewis, P. and Thornhill, A.(2009). Research Methods for Business Students, $3^{\text {rd }}$ Edition. Harlow: Pearson Education Ltd.

Schultz, T. P. (2005). Demographic determinants of Savings: Estimating and Interpreting the Aggregate Association in Asia. Institute of the Study of Labour. New Haven.

Schmidt-Hebbel, K., Webb, S. B. and Corsetti, G. (1992). Household Savings in Developing Countries: First Cross Country Evidence. The World Bank Review. Volume 6. No. 3 Page 529-547.

Standard Zimbabwe, 21 October, 2012

The 2017 National Budget Speech. Ministry of Finance and Economic Development.

The National Financial Inclusion Strategy, 2016 - 2020. Reserve Bank of Zimbabwe.

World Bank Report. (1998). Development Report 1998. Oxford University Press. New York.

World Bank Report (2013). World Bank National Accounts

Zimbabwe National Financial Inclusion Strategy 2016-2020. Reserve Bank of Zimbabwe.

Notes

Note 1

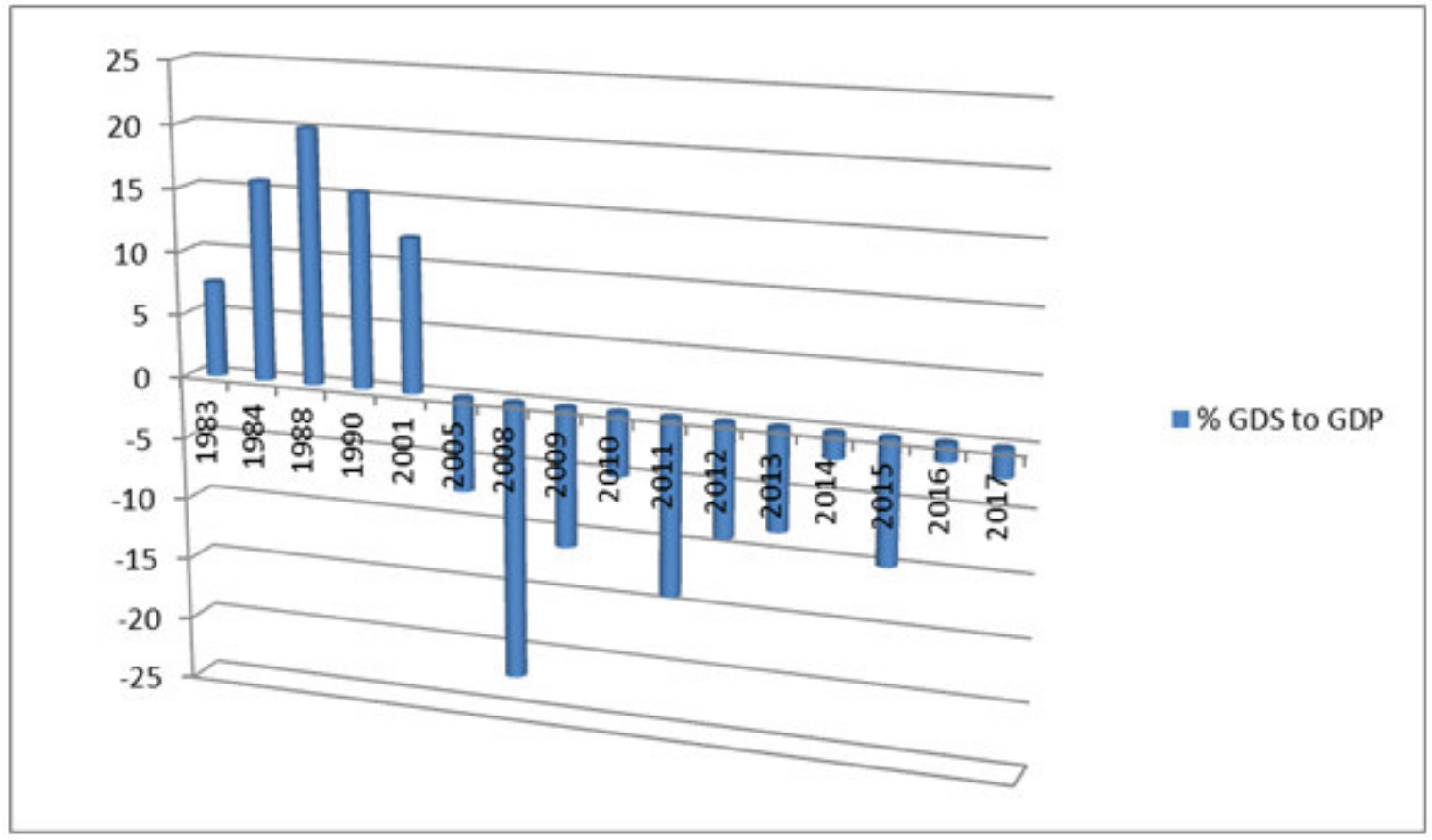

Figure 1.1: Gross Domestic Savings as percentage of GDP

Source: Adapted from the World Bank Indicators: Zimbabwe National Accounts. 
Note 2

Table 1.7.1: The Response Rate for the Questionnaire

\begin{tabular}{lcc}
\hline Response rate & Frequency & Percentage \\
\hline Returned & 170 & $85 \%$ \\
Unreturned & 30 & $15 \%$ \\
Total & $\mathbf{2 0 0}$ & $\mathbf{1 0 0 \%}$ \\
\hline
\end{tabular}

Source: Researcher

Note 3

Table 1.7.2: The Response Rate for the Interviews

\begin{tabular}{lccc}
\hline Respondents profile & Targeted Frequency & Actual Frequency & Percentage response rate \\
\hline Bankers & $\mathbf{7 4}$ & 60 & $81 \%$ \\
Micro-financiers & $\mathbf{2 8}$ & 23 & $82 \%$ \\
RBZ & $\mathbf{4}$ & 4 & $100 \%$ \\
Finance Ministry & $\mathbf{4}$ & 4 & $100 \%$ \\
DPC & $\mathbf{4}$ & 4 & $100 \%$ \\
Total & $\mathbf{1 1 4}$ & $\mathbf{9 5}$ & $\mathbf{8 3 \%}$ \\
\hline
\end{tabular}

Source: Researcher

Note 4

Table 1.7.3: Having an active bank account

\begin{tabular}{llrrrr}
\hline & Frequency & Percent & Valid Percent & Cumulative Percent \\
\hline Valid & Yes & 166 & 97.6 & 97.6 & 97.6 \\
& No & 4 & 2.4 & 2.4 & 100.0 \\
& Total & 170 & 100.0 & 100.0 & \\
\hline
\end{tabular}

Source: Researcher

Note 5

Table 1.7.4: Symmetric Measures for account activity and savings potential

\begin{tabular}{|c|c|c|c|c|c|}
\hline \multirow[b]{2}{*}{ Nominal } & & \multirow{2}{*}{$\begin{array}{l}\text { Value } \\
.423\end{array}$} & \multirow[t]{2}{*}{$\begin{array}{l}\text { Asymp. Std. } \\
\text { Error }^{\mathrm{a}}\end{array}$} & \multirow[t]{2}{*}{$\begin{array}{c}\text { Approx. } \\
\mathbf{T}^{\mathbf{b}}\end{array}$} & \multirow{2}{*}{$\begin{array}{l}\text { Approx. } \\
\text { Sig. } \\
.000\end{array}$} \\
\hline & Phi & & & & \\
\hline Nominal & Cramer's V & .299 & & & .000 \\
\hline \multirow[t]{2}{*}{ Ordinal by Ordinal } & Kendall's tau-b & .071 & .078 & .918 & .358 \\
\hline & Spearman Correlation & .073 & .085 & .954 & $.341^{\mathrm{c}}$ \\
\hline Interval by Interval & Pearson's R & .003 & .096 & .041 & $.967^{\mathrm{c}}$ \\
\hline $\mathrm{N}$ of Valid Cases & & 170 & & & \\
\hline $\begin{array}{l}\text { a. Not assuming the } \\
\text { b. Using the asympto } \\
\text { c. Based on normal a }\end{array}$ & $\begin{array}{l}\text { hypothesis. } \\
\text { tandard error assumi } \\
\text { oximation. }\end{array}$ & ull hy & esis. & & \\
\hline
\end{tabular}

Source: Researcher

Note 6

Table 1.7.5: Correlations of age and savings potential

\begin{tabular}{llcc}
\hline \multirow{3}{*}{ Age in years } & Age in years & Savings practice potential \\
& Sig. (2-tailed) & 1 & -.104 \\
& $\mathrm{~N}$ & & .177 \\
Savings practice potential & Pearson Correlation & -.104 & 170 \\
& Sig. (2-tailed) & .177 & 1 \\
& $\mathrm{~N}$ & 170 & 170 \\
\hline
\end{tabular}

Source: Researcher 
Note 7

Table 1.7.6: ANOVA for the age and the savings potential

\begin{tabular}{llccccc}
\hline Model & & Sum of Squares & Df & Mean Square & F & Sig. \\
\hline 1 & Regression & 144.201 & 1 & 144.201 & 1.842 & $.177^{\mathrm{b}}$ \\
& Residual & 13150.275 & 168 & 78.275 & & \\
\multicolumn{2}{l}{ Total } & 13294.476 & 169 & & & \\
a. Dependent Variable: Age in years & & & & \\
b. Predictors: (Constant), Savings practice potential & & & & \\
\hline
\end{tabular}

Source: Researcher

Note 8

Table 1.7.7: Main reason for saving

\begin{tabular}{llcccc}
\hline & Frequency & Percent & $\begin{array}{c}\text { Valid } \\
\text { Percent }\end{array}$ & $\begin{array}{c}\text { Cumulative } \\
\text { Percent }\end{array}$ \\
\hline Valid & Funding children's education & 39 & 22.9 & 22.9 & 22.9 \\
& $\begin{array}{l}\text { Property acquisition } \\
\text { Preparing a better life at }\end{array}$ & 45 & 26.5 & 26.5 & 49.4 \\
& retirement & & 24.1 & 24.1 & 73.5 \\
& & & & \\
& Illness and other emergencies & 11 & 6.5 & 6.5 & 80.0 \\
To acquire consumer durables & 11 & 6.5 & 6.5 & 86.5 \\
Travel and leisure & 9 & 5.3 & 5.3 & 1.8 \\
Others & 14 & 8.2 & 8.2 & 100.0 \\
Total & $\mathbf{1 7 0}$ & $\mathbf{1 0 0 . 0}$ & $\mathbf{1 0 0 . 0}$ & \\
\hline
\end{tabular}

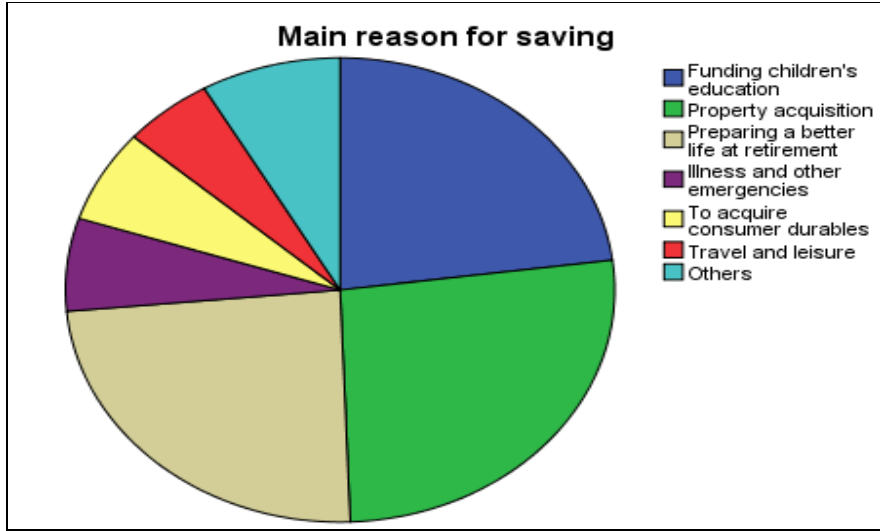

Figure 1.7.1: Main reasons for saving

Source: Researcher

Note 9

Table 1.7.8: Symmetric Measures for saving reason and banker selection

\begin{tabular}{|c|c|c|c|c|c|}
\hline & & Value & $\begin{array}{c}\text { Asymp. Std. } \\
\text { Error }^{\mathrm{a}}\end{array}$ & $\begin{array}{c}\text { Approx. } \\
T^{b}\end{array}$ & $\begin{array}{l}\text { Approx. } \\
\text { Sig. }\end{array}$ \\
\hline Nominal & Phi & .944 & & & .000 \\
\hline \multirow[t]{3}{*}{ Nominal } & Cramer's V & .422 & & & .000 \\
\hline & Contingency & .686 & & & .000 \\
\hline & Coefficient & & & & \\
\hline Interval by Interval & Pearson's R & .226 & .079 & 3.004 & $.003^{\mathrm{c}}$ \\
\hline Ordinal by Ordinal & Spearman Correlation & .174 & .081 & 2.291 & $.023^{\mathrm{c}}$ \\
\hline \multicolumn{2}{|l|}{$\mathrm{N}$ of Valid Cases } & 170 & & & \\
\hline \multicolumn{6}{|c|}{ a. Not assuming the null hypothesis. } \\
\hline \multicolumn{6}{|c|}{ b. Using the asymptotic standard error assuming the null hypothesis. } \\
\hline
\end{tabular}

Source: Researcher 
Note 10

Table 1.7.9: Gender and type of account held cross tabulation

\begin{tabular}{|c|c|c|c|c|c|c|c|c|}
\hline \multirow[b]{3}{*}{ Gender } & \multirow[b]{3}{*}{ Female } & \multirow[b]{3}{*}{ Count } & \multicolumn{5}{|c|}{ Type of account held } & \multirow[t]{2}{*}{ Total } \\
\hline & & & $\begin{array}{l}\text { Savings } \\
\text { account }\end{array}$ & $\begin{array}{l}\text { Current } \\
\text { account }\end{array}$ & $\begin{array}{c}\text { Call } \\
\text { account }\end{array}$ & $\begin{array}{l}\text { Time } \\
\text { deposit }\end{array}$ & Others & \\
\hline & & & 57 & 5 & 2 & 2 & 0 & 66 \\
\hline & \multirow{11}{*}{ Male } & within & $86.4 \%$ & $7.6 \%$ & $3.0 \%$ & $3.0 \%$ & $0.0 \%$ & $100.0 \%$ \\
\hline & & $\begin{array}{l}\text { Gender } \\
\% \text { within Type } \\
\text { of account held }\end{array}$ & $41.6 \%$ & $19.2 \%$ & $66.7 \%$ & $100.0 \%$ & $0.0 \%$ & $38.8 \%$ \\
\hline \multirow{9}{*}{ Total } & & $\%$ of Total & $33.5 \%$ & $2.9 \%$ & $1.2 \%$ & $1.2 \%$ & $0.0 \%$ & $38.8 \%$ \\
\hline & & Count & 80 & 21 & 1 & 0 & 2 & 104 \\
\hline & & $\begin{array}{l}\% \\
\text { Gender }\end{array}$ & $76.9 \%$ & $20.2 \%$ & $1.0 \%$ & $0.0 \%$ & $1.9 \%$ & $100.0 \%$ \\
\hline & & $\begin{array}{l}\% \text { within Type } \\
\text { of account held }\end{array}$ & $58.4 \%$ & $80.8 \%$ & $33.3 \%$ & $0.0 \%$ & $100.0 \%$ & $61.2 \%$ \\
\hline & & $\%$ of Total & $47.1 \%$ & $12.4 \%$ & $0.6 \%$ & $0.0 \%$ & $1.2 \%$ & $61.2 \%$ \\
\hline & & Count & 137 & 26 & 3 & 2 & 2 & 170 \\
\hline & & $\% \quad$ within & $80.6 \%$ & $15.3 \%$ & $1.8 \%$ & $1.2 \%$ & $1.2 \%$ & $100.0 \%$ \\
\hline & & $\begin{array}{l}\% \text { within Type } \\
\text { of account held }\end{array}$ & $100.0 \%$ & $100.0 \%$ & $100.0 \%$ & $100.0 \%$ & $100.0 \%$ & $100.0 \%$ \\
\hline & & $\%$ of Total & $80.6 \%$ & $15.3 \%$ & $1.8 \%$ & $1.2 \%$ & $1.2 \%$ & $100.0 \%$ \\
\hline
\end{tabular}

Source: Researcher

Note 11

Table 1.7.19: Chi-Square Tests for gender and type of account held

\begin{tabular}{lccc} 
& Value & Df & Asymp. Sig. (2-sided) \\
\hline Pearson Chi-Square & $10.049^{\text {a }}$ & 4 & .040 \\
Likelihood Ratio & 11.785 & 4 & .019 \\
Linear-by-Linear Association & .453 & 1 & .501 \\
N of Valid Cases & 170 & & \\
a. 6 cells (60.0\%) have expected count less than 5. The minimum expected count is .78. \\
\hline
\end{tabular}

Source: Researcher

Note 12

Table 1.7.11: Symmetric Measures for gender and type of account held

\begin{tabular}{|c|c|c|c|c|c|}
\hline & & Value & $\begin{array}{l}\text { Asymp. Std. } \\
\text { Error }^{\mathrm{a}}\end{array}$ & $\begin{array}{c}\text { Approx. } \\
T^{b}\end{array}$ & $\begin{array}{l}\text { Approx. } \\
\text { Sig. }\end{array}$ \\
\hline Nominal & Phi & .243 & & & .040 \\
\hline Nominal & Cramer's V & .243 & & & .040 \\
\hline Interval by Interval & Pearson's R & .052 & .075 & .672 & $.503^{\mathrm{c}}$ \\
\hline Ordinal by Ordinal & Spearman Correlation & .105 & .073 & 1.363 & $.175^{\mathrm{c}}$ \\
\hline \multicolumn{6}{|c|}{$\begin{array}{l}\text { a. Not assuming the null hypothesis. } \\
\text { b. Using the asymptotic standard error assuming the null hypothesis. } \\
\text { c. Based on normal approximation. }\end{array}$} \\
\hline
\end{tabular}


Note 13

Table 1.7.12: Province account held

\begin{tabular}{llcccc}
\hline & Frequency & Percent & Valid Percent & Cumulative Percent \\
\hline Valid & Bulawayo & 16 & 9.4 & 9.4 & 9.4 \\
& Harare & 85 & 50.0 & 50.0 & 59.4 \\
Manicaland & 2 & 1.2 & 1.2 & 60.6 \\
Mash central & 3 & 1.8 & 1.8 & 62.4 \\
Mash east & 8 & 4.7 & 4.7 & 67.1 \\
Mash west & 32 & 18.8 & 18.8 & 85.9 \\
Masvingo & 1 & .6 & .6 & 86.5 \\
Mat north & 5 & 2.9 & 2.9 & 89.4 \\
Mat south & 1 & .6 & .6 & 90.0 \\
Midlands & 17 & 10.0 & 10.0 & 100.0 \\
Total & $\mathbf{1 7 0}$ & $\mathbf{1 0 0 . 0}$ & $\mathbf{1 0 0 . 0}$ & \\
\hline
\end{tabular}

Source: Researcher

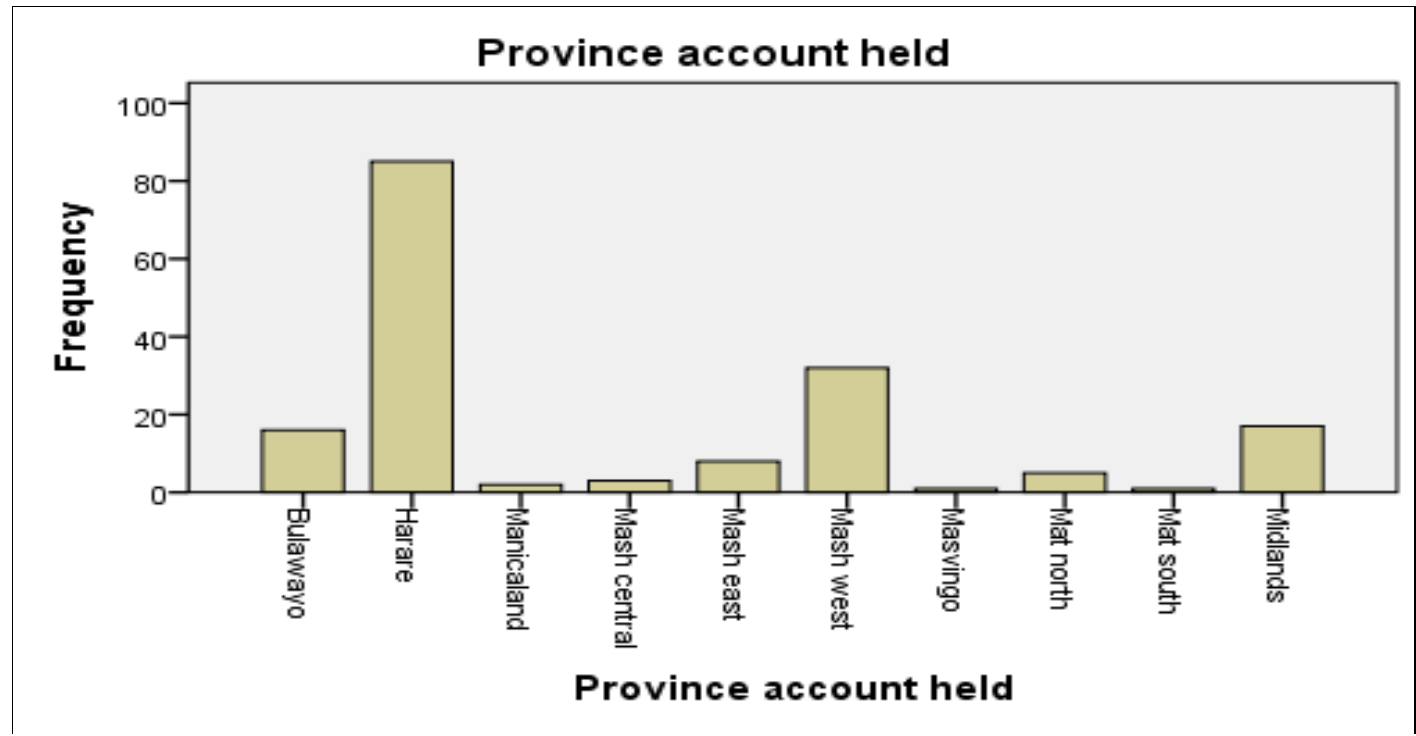

Figure 1.7.2: Province account is held.

Source: Researcher

Note 14

Table 1.7.13: ANOVA for Savings potential and province account is held

\begin{tabular}{llccccc}
\hline Model & & Sum of Squares & Df & Mean Square & F & Sig. \\
\hline 1 & Regression & 9.286 & 1 & 9.286 & 1.167 & $.282^{\mathrm{b}}$ \\
& Residual & 1336.808 & 168 & 7.957 & & \\
& Total & 1346.094 & 169 & & &
\end{tabular}

a. Dependent Variable: Savings potential

b. Predictors: (Constant), Province account held

Source: Researcher

Note 15

Table 1.7.14: Model Summary for Savings potential and province account is held

\begin{tabular}{|c|c|c|c|c|c|c|c|c|c|}
\hline \multirow[t]{2}{*}{ Model } & \multirow[t]{2}{*}{$\mathbf{R}$} & \multirow{2}{*}{$\begin{array}{c}\mathbf{R} \\
\text { Square }\end{array}$} & \multirow{2}{*}{$\begin{array}{l}\text { Adjusted } \\
\text { R Square }\end{array}$} & \multirow{2}{*}{$\begin{array}{c}\text { Std. } \\
\text { Error of } \\
\text { the } \\
\text { Estimate }\end{array}$} & \multicolumn{5}{|c|}{ Change Statistics } \\
\hline & & & & & $\begin{array}{c}\mathrm{R} \\
\text { Square } \\
\text { Change }\end{array}$ & $\begin{array}{c}\mathrm{F} \\
\text { Change }\end{array}$ & df1 & $\mathrm{df} 2$ & $\begin{array}{c}\text { Sig. F } \\
\text { Change }\end{array}$ \\
\hline 1 & $.083^{\mathrm{a}}$ & .007 & .001 & 2.829 & .007 & 1.167 & 1 & 168 & .331 \\
\hline
\end{tabular}

Source: Researcher 
Note 16

Table 1.7.15: Frequency of bank visit

\begin{tabular}{llrrrr}
\hline & \multicolumn{1}{c}{ Frequency } & \multicolumn{1}{c}{ Percent } & Valid Percent & Cumulative Percent \\
\hline Valid & Daily & 7 & 4.1 & 4.1 & 4.1 \\
& Weekly & 21 & 12.4 & 12.4 & 16.5 \\
& Monthly & 86 & 50.6 & 50.6 & 67.1 \\
& Yearly & 33 & 31.2 & 31.2 & 98.2 \\
& Never & 1.8 & 1.8 & 100.0 \\
& Total & $\mathbf{1 7 0}$ & $\mathbf{1 0 0 . 0}$ & $\mathbf{1 0 0 . 0}$ &
\end{tabular}

Source: Researcher

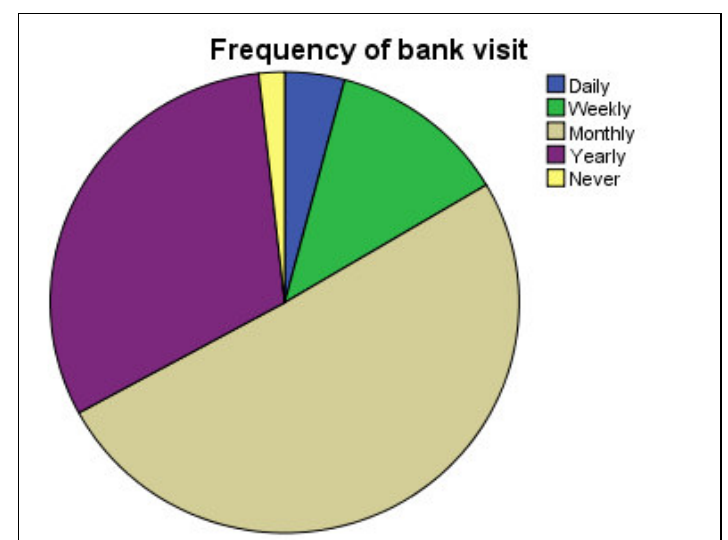

Figure 1.7.3: Frequency of bank visit

Source: Researcher

Note 17

Table 1.7.16: Form of wealth

\begin{tabular}{llrrrr}
\hline & Frequency & Percent & $\begin{array}{c}\text { Valid } \\
\text { Percent }\end{array}$ & $\begin{array}{c}\text { Cumulative } \\
\text { Percent }\end{array}$ \\
\hline Valid & Financial assets (shares & 30 & 17.6 & 17.6 & 17.6 \\
& etc) & & & & \\
& Livestock & 24 & 14.1 & 14.1 & 31.8 \\
& Properties & 85 & 50.0 & 50.0 & 81.8 \\
Movable assets like cars & 31 & 18.2 & 18.2 & 100.0 \\
& Total & $\mathbf{1 7 0}$ & $\mathbf{1 0 0 . 0}$ & $\mathbf{1 0 0 . 0}$ & \\
\hline
\end{tabular}

Source: Researcher

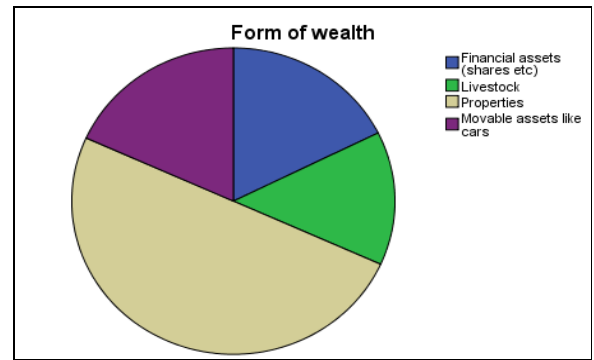

Source: Researcher

Figure 1.7.4: Form of wealth 
Note 18

Table 1.7.17: Economic factor

\begin{tabular}{llcccc}
\hline & Frequency & Percent & Valid Percent & Cumulative Percent \\
\hline Valid & Strongly agree & 134 & 78.8 & 78.8 & 78.8 \\
& Agree & 23 & 13.5 & 13.5 & 92.4 \\
& Not sure & 7 & 4.1 & 4.1 & 96.5 \\
Disagree & 2 & 1.2 & 1.2 & 97.6 \\
& Strongly disagree & 4 & 2.4 & 2.4 & 100.0 \\
& Total & $\mathbf{1 7 0}$ & $\mathbf{1 0 0 . 0}$ & $\mathbf{1 0 0 . 0}$ & \\
\hline
\end{tabular}

Source: Researcher

Note 19

Table 1.7.18: Credibility of institutions

\begin{tabular}{llrrrr}
\hline & Frequency & Percent & $\begin{array}{c}\text { Valid } \\
\text { Percent }\end{array}$ & $\begin{array}{c}\text { Cumulative } \\
\text { Percent }\end{array}$ \\
\hline Valid & Strongly agree & 79 & 46.5 & 46.5 & 46.5 \\
& Agree & 37 & 21.8 & 21.8 & 68.2 \\
& Not sure & 32 & 18.8 & 18.8 & 87.1 \\
& Disagree & 13 & 7.6 & 7.6 & 94.7 \\
& Strongly disagree & 9 & 5.3 & 5.3 & 100.0 \\
& Total & $\mathbf{1 7 0}$ & $\mathbf{1 0 0 . 0}$ & $\mathbf{1 0 0 . 0}$ & \\
\hline
\end{tabular}

Source: Researcher

Note 20

Table 1.7.19: Political factor view

\begin{tabular}{llcccc}
\hline & Frequency & Percent & $\begin{array}{c}\text { Valid } \\
\text { Percent }\end{array}$ & $\begin{array}{c}\text { Cumulative } \\
\text { Percent }\end{array}$ \\
\hline Valid & Strongly agree & 112 & 65.9 & 65.9 & 65.9 \\
& Agree & 36 & 21.2 & 21.2 & 87.1 \\
& Not sure & 17 & 10.0 & 10.0 & 97.1 \\
& Disagree & 2 & 1.2 & 1.2 & 98.2 \\
& Strongly disagree & 3 & 1.8 & 1.8 & 100.0 \\
& Total & $\mathbf{1 7 0}$ & $\mathbf{1 0 0 . 0}$ & $\mathbf{1 0 0 . 0}$ & \\
\hline
\end{tabular}

Source: Researcher 